\title{
The Leadership Effect on Employees Motivation
}

\author{
Henrique Guilherme Scatolin, Rafael Barranco, Robson Pereira de Torres \\ Uniararas, São Paulo, Brazil
}

\begin{abstract}
This paper discusses the effect that the leadership causes on employees' motivation within the organizations, in order to show the reader that leadership is an external stimulus necessary to awaken the employees' intrinsic feelings, among them, the motivation. The leader faces constant challenges in the organization day by day and he is responsible for understanding his lead team, as well as their several natures and cultural models. In the classical theory, people worked in a mechanistic manner with the motivation, but with the industrial development and the competitiveness incitement, it was observed that to survive on the market, companies need to extract as much as possible of the intellectual capital of its human factor. Therefore, it is necessary to establish conditions under which people feel motivated to work towards the goals outlined by the companies, thus obtaining satisfactory results. This article concludes that motivation is an internal force that is directly affected by external factors in which the manager is responsible for identifying what really motivates each employee in the search for the best results.
\end{abstract}

Keywords: leadership, motivation, satisfaction

\section{Introduction}

The world societies are living in an era where the globalization, information speed, and technology are quickly renewed, increasing the markets competitiveness. For settling into such competitive market, companies need to extract the best from their employees, placing them in a position to accomplish their goals and commitments within deadlines, ensuring total satisfaction to their customers and thus keeping fully heated in the market. For this purpose, "Structure is required where leadership and motivation walk together to achieve the final product with satisfactory results" (Nakamura et al., 2005).

Although there is no concrete and fully applicable definition, many authors have already discussed the motivation and leadership topic and presented several theories related to the topic. Among them, the following are highlighted: Abraham Maslow, Victor Vroom, McGregor, Bowditch and Buono, White and Lippitti, Rensis Likert, among others.

Therefore, this paper highlights, through a bibliographical review, that to achieve results within an organization, it is necessary that "The entire team is with one goal in common, and this difficult trajectory should be guided by the leader, who needs to have a broad and directional vision within an organization" (Russo et al., 2005, p. 3).

\footnotetext{
Henrique Guilherme Scatolin, Doctor and master's degree in Psychology from the Pontifical Catholic University of São Paulo, graduated in Psychology from Unimep (Methodist University of Piracicaba). Currently, is a professor in the Accounting Course of FHO Uniararas.

Rafael Barranco, Graduated in Accounting from FHO Uniararas.

Robson Pereira de Torres, Graduated in Accounting from FHO Uniararas.
} 


\section{Research Methodology}

This article is based on a bibliographical review through research in books and papers on human resources, scientifically contributing for the study of the intrinsic relationship between leadership and motivation. For Cervo and Bervian (2004):

The bibliographical research is the formation means for excellence and constitutes the basic procedure for the monographic studies, by which the state-of-the-art domain is searched on the given topic. As an original scientific work, the research itself is constituted in the human sciences area. As a subject summary, it usually constitutes the first step of any scientific research. (p. 65)

\section{Theoretical Referential}

\section{Work Development History}

According to Nobre (2010), since prehistoric times, man realized that work was essential for his survival and with that he started to value the other human beings. Then the teamwork was proposed, which soon took large proportions and men began to live in society.

With this came the need for someone that was a leading reference for the members of the new organizations. This individual would be responsible for the establishment and compliance of rules that would govern societies. Consequently, the figure of the leader was born.

The years were passing and the human being became more civilized and organized, until passing through the period known as the Industrial Revolution, in which the artisanal work structure was transformed into manufacturing.

From 1860, the companies had a super production increase, generating a disorganized growth in industries. Soon, several work understanding methods began to emerge, such as that of Frederick Taylor, focusing on the production standardization, and Fayol's that worked the company organization as a whole. Unlike Taylor and Fayol, Elton Mayo develops the human relations theory, which establishes the person as the organization primary focus, and the well-being at work, leadership and motivation concepts are created.

Currently, the world passes through a technical revolution and the global economy has been increasingly balanced, and several countries that were "poor" before are now in total ascension and being known as emerging. The work efficiency is no longer brachial and became intellectual, and companies have already noticed that innovation is essential in this so competitive market. Therefore, "Innovation is no longer in machines but in the human intellect" (Nobre, 2010, p. 30).

\section{Current Scenario of People Management}

Given this scenario, the issue on how to awaken the knowledge stored within the man began to be discussed, and it was noticed that quality leadership is one of the keys to awake the human motivation.

A properly led environment within the skills developed, such as respect, understanding, and altruism create a motivation to lead, making the entire process of a project, from the beginning until the end if its execution, leave the target audience satisfied. Many studies on the subject show that "Employees motivated and recognized for their work produce better and this makes the members of a team have the same goals to accomplish and be within the company's strategy" (Nakamura et al., 2005, pp. 20-25).

For Chiavenato (2004), "The administrator needs to know the human nature and know how to conduct people, i.e., to lead" (p. 122). In view of this quote, we can launch the following questions: Do current leaders 
"create" an environment favorable to their subordinates and, do they know the difference between power and authority? Let us remember that for many long years, the figure of a leader was related to the ultimate authority of power. Under no circumstances, he could be questioned, receive opinions or praise his led by the goal achieved. This way, he could lose his control power.

Since the early 20th century to the present day, there are still teams working in a hostile environment, inspired by the classical tayorist-fordist theory where there is a maximum efficiency in production and management able to exert full control over the workers. If, on one hand, there is a scenario inspired in the classical theory, on the other, there is an ideal scenario where the great business managers know that, to keep their companies in the unstable market, the human factor must come in the foreground.

So, people are different regarding motivation, because the needs vary according to each person's personality and this produces, according to Chiavenato (1999), different behavioral patterns... due to the cultural values of each individual (pp. 88-89).

\section{Motivational Theories}

One of the most remembered theories on motivation is the one of Abraham Maslow that defines motivation as "something constant and complex found in all human beings" (as cited in França et al., 2002, p. 251).

For Maslow:

Man is an animal that desires and that rarely reaches a state of complete satisfaction, except for a short time. As he satisfies a desire, comes another one to take its place. When this is pleased another arises in the background. It is the human being characteristic, and his entire life, he always desires something. (as cited in França et al., 2002, p. 251)

Abraham Maslow formulated his theory about the motivation based on a hierarchy of needs, which were divided into the primary physiologic needs and the security and secondary needs that would be the "social needs, the esteem needs, and the self-realization needs" (Chiavenato, 1999, pp. 88-89).

The physiological and safety needs are the basis of Maslow's pyramid. The physiological needs are related to primary needs such as hunger, thirst, and sex, and the safety needs are related to concerns with safety and shelter. After the satisfaction of this need, people start worrying about the social needs.

Social needs are the needs including friends, girlfriend/boyfriend, wife/husband, children, etc.. The individual feels the need to be estimated by other people and this is perhaps the area of the greatest danger within the human motivation.

The need for self-esteem is a result of satisfaction even if partial of the other three, because the human being starts to need self-confidence feelings, sense of usefulness and value to the world. Finally, it appears the self-realization need that comprises "the realization of all other needs. This occurs when the man reaches the maximum potential and becomes more than he really is as a person" (França, 2002, p. 253).

For Victor Vroom, each individual has preferences for certain results and this influences the productivity of each person. For Vroom (as cited in Chiavenato, 1999, pp. 88-89), “An individual increases its capacity and performance when three factors are gathered: personal objectives, relation perceived between satisfaction and high productivity, and perception of his capacity to influence his productivity". These three factors are crucial in the motivation of the organization member.

Another known theory is the $\mathrm{X}$ and $\mathrm{Y}$, proposed in 1957 by McGregor (as cited in Nobre, 2010). The $\mathrm{X}$ is referring to organizations based on the traditional management mode, where the employee is understood as a 
frivolous human being and without growth perspectives, which can be controlled by financial incentives. And the $\mathrm{Y}$ refers to the organizations that have a modern management, based on human development, providing confidence and autonomy for the tasks definition. The Y, according to Nobre (2010), "decentralizes the power and creates a democratic and participatory environment, by which people feel motivated by the conditions proposed in the management" (pp. 47-48).

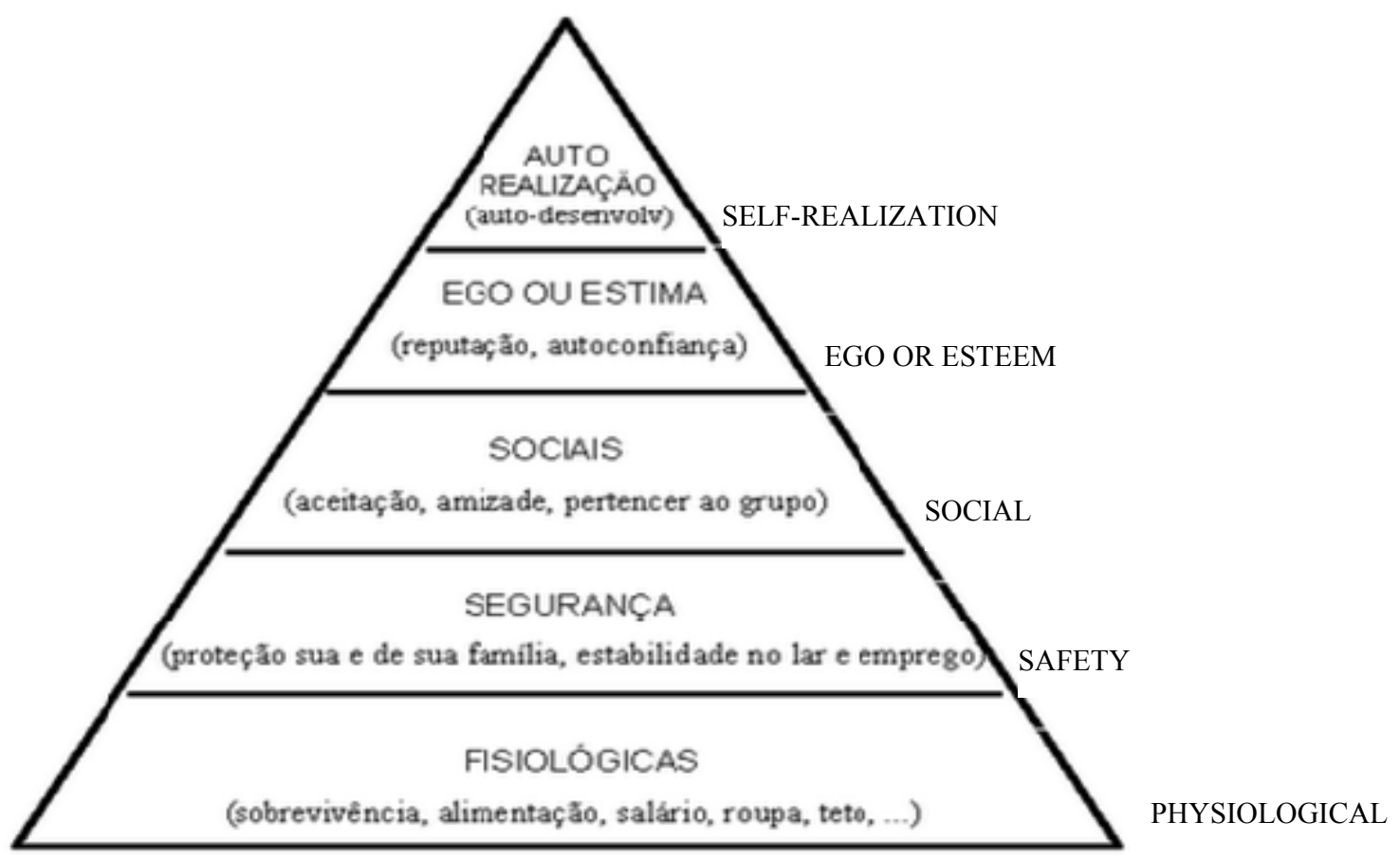

Figure 1. Source: Retrieved from http://motivaeinova.blogspot.com.br/2012/02/piramide-de-maslow-entenda-hierarquia.html

Each theory above presents an understanding regarding the human nature and no theory can tell you all about the motivation of each person. In view of this, the motivation is extremely subjective and it is influenced not only by extrinsic factors, but also by intrinsic factors that "vary from person to person, and this peculiarity makes it too complex to deal with motivational processes" (França, 2002, p. 257).

Against this complexity, a question hangs over the companies: The own person is auto-motivated or motivation must be managed? For Chiavenato (1994), "Motivation is one of the main managerial responsibilities" (p. 166). The motivation is within the individual, but the leader is responsible for influencing this motivation through a quality environment, where the intrinsic factors join to the extrinsic factors.

\section{Leadership Theories and Styles}

There are several definitions of leadership, among which we mention the one of Bowditch and Buono (1992) that defined it as "an influence process, usually from a person, through which an individual or group is oriented for the establishment and achievement of goals" (p. 118).

In addition to this definition, many theorists have formulated theories and styles regarding leadership in organizations. Regarding the leadership styles, White and Lippitt (as cited in Chiavenato, 1994) analyzed the impact caused by three basic types of leadership: the autocratic, liberal, and democratic. Autocratic leadership presented a great workload, but there were signs of tension and frustration, the liberal leadership was bad in 
production and quality, and with strong signs of individualist and disrespect towards the leaders. And in the democratic leadership, the groups did not produce as the autocratic leadership, but the work quality, satisfaction and commitment were amazing. With this, it was concluded that "the autocracy overloads the leader, the liberalism overloads the subordinates, and the democracy balances the responsibilities of the individuals involved in the organization" (Chiavenato, 1994, pp. 149-150).

Other two leadership styles are the leadership centered on the task, which deals with a leadership style focused on defining the task and obtaining results through the work standardization, using a classical model closer to a company classified in the theory X. Another is the leadership centered on person, in which there is a greater concern with the subordinates and which seeks to keep a team motivated and focused on the goal, and not only in methods. This leadership model is "more interactive and the leader acts more as a supporter and shows full confidence in his team" (Chiavenato, 1994, pp. 151-152).

Rensis Likert (as cited in Quimet, 2002) argues that managers are members of two groups within an organization. In one group, he is responsible for the people, in other words, it would be the low group, and the other would be the top group, in which he is the subordinate of his superiors. In this theory, the effective leadership would exert influence over the top group and, at the same time, he would be able to lead the low group. This would be, according to Bowditch and Buono (1992), the link to encourage the team to obtain the results for their superiors, providing a real satisfaction to the leader towards both groups (pp. 123-124).

\section{Effects on the Accounting Management}

Bringing these motivation and leadership theories to the accounting and administrative field where the accountant usually coordinates a group of people, and he is also responsible for providing relevant information for decision-making; the accountant needs to exert an important leadership activity towards his led team, where he learns to observe his leadership style in order to strengthen his individual performance and evaluate the situation he is living within the organization.

An organization without motivated personal and with a work environment unfavorable has a vital strategic deficiency. People without personal and professional development are also a problem of business management. It is favorable that "The accounting manager keeps a management focused on developing people with high performance expectations and professional challenges" (Bernardi, 2003, p. 136).

The accountant/controller ${ }^{1}$ needs to have confidence in his team, because there is no way to manage people without providing them confidence. When the manager transmits safety to the team, he informally establishes a cooperation agreement with the involved and this provides the commitment of the person with his own, making the organization interests align with his personal and professional growth interests. A leadership with little confidence creates controls that leave the company very hierarchical and bureaucratic. This frustrates, according to Covey (2002), "to achieve goals because the processes become very exhaustive and this reflects directly on the desired result" (pp. 145-146).

The controller occupies an important position in the organization management team. He is the information man and who has the future vision, being able to identify the failures to be corrected and to indicate the best paths for the organization success. The controller must be ethical and fair, a people manager and mentor of new professionals. He should be, according to Crepaldi (2008), "a helper of other managers, assisting all

\footnotetext{
${ }^{1}$ Responsible for the controllership department and the analysis of the companies' quantitative information.
} 
departments to achieve their goals. His criticisms should be constructive and through respectful and suggestive means" (pp. 29-30).

The company controllership area is fueled by information from the accountant, and being analyzed and processed by the controller, who assumes the responsibility of centralizing the efforts and ordering the organization managers actions. And within those procedures "are the behavioral changes necessary to ensure that the company can achieve its mission and maximize the wealth of all those involved in the institution" (Borba, 2009, p. 30).

\section{Conclusion}

Motivation is an inner strength that makes people search for the self-realization. Even in the face of major challenges and obstacles, the motivated individual struggles to win and overcome.

The leader that knows the motivational basis of his team can deal with people in an individualized way, in order to establish a relationship of trust and with this he "will generate a motivational impulse in people, transforming the inner motivation in attitudes and consequently, he will get the maximum of his subordinates" (Davis \& Newstron, 2004, pp. 45- 46).

Currently we live in a technological era and the information circulation is constant. Every moment, the market changes and a product must always be renewed. Therefore, the company needs to adapt to the market, i.e., innovate and anticipate to the facts.

For materializing the planning into results, the organization needs people capable of achieving the goals and developing improvements, being the innovation a key factor in today's world. To achieve the innovation, it is necessary to have human capital and this capital needs to be extracted and drawn by external factors, such as through the leadership, confidence, and autonomy. This will arouse the motivation necessary to develop new skills and produce new ideas. And although there is a maximal theory to achieve people motivation awakening, the leader needs to identify the personality of each component of his team, in order to extract the best from each individual and obtain results that will reflect in the corporation balance sheets and income statements.

\section{References}

Bejarano, V. C., \& Pilatti, L. A. (2008). External elements essential to the teams implementation. Revista de Administração, $43(1)$.

Bernardi, L. A. (2003). Entrepreneurship and management handbook: Fundamentals, strategies and dynamics. São Paulo: Atlas.

Borba, V. S. (n.d.). The importance of the controller role in the economic management. Retrieved March 10th, 2012, from http://www.avm.edu.br

Bowditch, J. L., \& Buono, A. F. (1992). Elements of organizational behavior. São Paulo: Pioneira Thomson.

Brandt, J. A., \& Oliveira, I. C. (2009). Analysis of the supervisors relations with their teams in the work organizations. Psicologia USP, 20(4).

Cervo, A. L., \& Bervian, P. A. (2004). Scientific methodology (5th ed.). São Paulo: Prentice Hall.

Chiavenato, I. (1999). Human resource management (4th ed.). São Paulo: Atlas.

Chiavenato, I. (2004). Administration in new times (2nd ed.). Rio de Janeiro: Elsevier.

Chiavenato, I. (1994). Managing people (3rd ed.). São Paulo: Makron Books.

Covey, S. R. (2002). Principle-based leadership (7th ed.). Rio de Janeiro: Elsevier.

Crepaldi, S. A. (2008). Accounting management: Theory and practice (4th ed.). São Paulo: Atlas.

Davis, K., \& Newstrom, J. W. (2004). Human behavior at work (1st ed.). São Paulo: Thomson Learning.

França, A. C. L. (2002). People in the organization (6th ed.). São Paulo: Gente. 
Mourão, L., \& Marins, J. (2010). Who is motivated to learn in the courses offered by the companies? Revista Paidéia, 20(46). Nakamura, C. C. et al. (2005). Motivation at work. Revista de Ciências Empresariais, 2(1).

Nobre, T. L. (2010). Motivation: The human resources management challenges today. Curitiba: Juruá.

Quimet, G. (2002). The Pitfalls of Leadership Paradigms. Revista de Administração, 42(2).

Russo, R. et al. (2005). Leadership and influence in the project management phases. Revista Produção, 15(3). 